Environment Conservation Journal 15(3) 85-88, 2014

ISSN 0972-3099 (Print) 2278-5124 (Online)

Abstracted and Indexed

\title{
Experimental studies on leucocyte response in contact dermatitis induced by calcium chromate
}

\section{Vibha Dube}

Received:14.08.2014

Revised: 12.10 .2014

Accepted:02.11.2014

\begin{abstract}
Contact dermatitis was induced in mice by injecting various concentrations of calcium chromate through subcutaneous route. Leucocyte response in these experimental mice was assessed on the basis of increase/decrease in total and differential counts which significantly differed as compared to those of respective controls. Total leucocyte counts increased significantly. A remarkable increase was also observed in lymphocyte, monocyte and eosinophil counts. Neutrophil and basophil counts decreased in the test groups. It emphasizes that contact dermatitis induced by chromium is delayed hypersensitivity reaction and is mediated through the sensitized cells. Pharmacological mediators released following degranulation of these cells play an important role in allergic reactions.
\end{abstract}

Keywords: Calcium chromate, contact dermatitis, delayed hypersensitivity, leucocyte-response

\section{Introduction}

Hexavalent chromium (Cr VI) compounds are biologically important because of their predominance and stability in the ambient environment and their toxicological characteristic (Daugherty, 1992 and ATSDR, 1989). Almost all the hexavalent $\mathrm{Cr}$ compounds in the environment arise from human activities. These compounds are used in ferro chrome production, electroplating, pigment production and tanning. Most important among Cr VI compounds is calcium chromate. It is most common allergen and of great importance in causing occupational contact dermatitis (EHC 61, 1988). A number of effects can result from occupational dermal exposure to $\mathrm{Cr}$ VI including irritative lesion of skin, inflammation and allergic reactions (Edmundson, 1951). Results of many studies (Fregert, 1975; Kvitko, 2001) suggested that exposure to Cr VI, through skin contact can pose serious health problem for the general population. A large number of biologically active substances and metals including $\mathrm{Cr}$ may have directly primary or secondary effects on immune system (Shrivastava etal, 2002), Some of them give rise to disordered functions of immune system resulting in increased susceptibility to infection, a variety of hypersensitivity reactions and autoimmune

Author's Address

Department of Zoolgy,Govt. Holkar Science college Indore

E-mail:vibhadube12@gmail.com diseases. Cr VI is of significant importance being an immunotoxic compound causing Immunosupression, allergy and inflammation (Luster et aI, 2000). The present study would elucidate the role of various leucocytes in the exhibition of delayed hypersensitivity responses. It may eventually help in analyzing factors involved in the hypersensitivity mechanisms caused by exposure to chromium.

\section{Materials and Methods}

Inbred Swiss albino mice Musmusculus albinus, 6-8 weeks old and 20-25 gms in weight were selected as the experimental animals. These mice were treated, with various concentrations (viz., $0.5 \%$, $1.0 \%$ and $2.0 \%$ ) of calcium chromate. These were injected subcutaneously on the ventral side of abdomen of mice. For the injection tubeculin syringe with 26 gauge, $1 \mathrm{~cm}$ long needle was used. Experimental mice became sensitized in 35 days when treated with $0.5 \%$ conc. nd in 30 days when exposed to $1.0 \%$ and $2.0 \%$ of calcium chromate. Twenty four (24) hours after the injection delayed hypersensitivity reaction was manifested in the form of contact dermatitis. The main characteristic features of chromium-induced contact dermatitis were erythema, oedema, papules and vesicles. After inducing contact dermatitis the mice were sacrificed under mild ether anesthesia and blood 
samples were collected aseptically by cardiac puncture. Respective controls were also maintained. Total and differential leucocyte counts were assessed according to the usual methods described by Raj Gopal and Ram Krishnan (1983) and Harold (1988).

\section{Results and Discussion}

Total leucocyte count was $7.900 \pm 0.447$ in control. The values increased signficantlyin all the treated groups, after 24 hours of exposure. The count was $8.80 \pm 0.894$ at lowest conc. (TCaChr1), 9.20 \pm 0.632 at medium conc. (TCaChr2) and $9.55 \pm 0.623$ at highest conc. (TCaChr3), table 1. A remarkable increase was observed in lymphocyte, monocyte and eosinophil counts. Neutrophil and basophil counts are found to be decreased in the experimental groups (Fig. 1).

Lymphocyte - In control the value was $56 \pm 0.44$. The minimum increase in the value was observed in $\mathrm{TCaChr} 1$ group $(57.75 \pm 0.632)$ and maximum in TCachr3 group $(60.75 \pm 0.312)$. Statically significant differences were observed among all the groups except that between 3 vs 4 .

Monocyte- the control value was $2.0 \pm 0.123$.the minimum count was $2.50 \pm 0.41$ and maximum $3.00 \pm 0.050$ inTCaChr1 andTCaChr3 groups respectively.

Eosinophil- the value was $2.0 \pm 0.031$ in control. Among experimental groups the counts were $2.60 \pm 0.043,2.85 \pm 0.362,3.05 \pm 0.418$ in TCaChr 1 , $\mathrm{TCaChr} 2, \mathrm{TCaChr} 3$ groups respectively.

Table 1:Haematological values after 24 hours of exposure in mice treated with calcium chromate

\begin{tabular}{|c|c|c|c|c|c|c|c|c|c|}
\hline \multirow{3}{*}{$\begin{array}{l}\text { Gr. } \\
\text { No }\end{array}$} & \multirow[t]{3}{*}{ Groups } & \multicolumn{8}{|c|}{ Differential Leucocyte count } \\
\hline & & \multirow{2}{*}{$\begin{array}{l}\text { TLC/cumm. } \\
\left(\text { TLC } \times 10^{3}\right)\end{array}$} & $\mathbf{N}$ & \multicolumn{2}{|l|}{$\mathbf{L}$} & $\mathbf{M}$ & B & \multicolumn{2}{|l|}{$\mathbf{E}$} \\
\hline & & & $\%$ & $\%$ & & $\%$ & $\%$ & $\%$ & \\
\hline 1. & NTC & $7.90 \pm 0.447$ & $\begin{array}{l}39.00 \\
0.044\end{array}$ & $\begin{array}{l}56.00 \\
0.044\end{array}$ & \pm & $\begin{array}{l}2.00 \\
+0.123\end{array}$ & $\begin{array}{ll}1.00 & \pm \\
0.031 & \end{array}$ & $\begin{array}{l}2.00 \\
0.031\end{array}$ & \pm \\
\hline 2. & $\mathrm{TCaChr}_{1}$ & $8.80 \pm 0.894$ & $\begin{array}{l}36.90 \\
0.223\end{array}$ & $\begin{array}{l}57.75 \\
0.632\end{array}$ & \pm & $\begin{array}{l}2.50 \\
+0.041\end{array}$ & $\begin{array}{ll}0.25 & \pm \\
0.064\end{array}$ & $\begin{array}{l}2.60 \\
0.043\end{array}$ & \pm \\
\hline 3. & $\mathrm{TCaChr}_{2}$ & $9.20 \pm 0.632$ & $\begin{array}{l}34.40 \\
0.316\end{array}$ & $\begin{array}{l}59.50 \\
0.442\end{array}$ & + & $\begin{array}{l}2.75 \\
+0.774\end{array}$ & $\begin{array}{ll}0.50 & \pm \\
0.021 & \end{array}$ & $\begin{array}{l}2.85 \\
0.362\end{array}$ & \pm \\
\hline 4. & $\mathrm{TCaChr}_{3}$ & $9.55 \pm 0.632$ & $\begin{array}{l}32.90 \pm \\
0.03\end{array}$ & $\begin{array}{l}60.75 \\
0.312\end{array}$ & & $\begin{array}{l}3.00 \\
+0.050\end{array}$ & $\begin{array}{ll}0.30 & \pm \\
0.532 & \end{array}$ & $\begin{array}{l}3.05 \\
0.418\end{array}$ & \pm \\
\hline
\end{tabular}

NTC $=$ Non Treated Control., $\mathrm{TCaChr}_{1}=$ Treated with $0.5 \%$ Calcium chromate. $\mathbf{T C a C h r}_{2}=$ Treated with $\mathbf{1 . 0 \%}$ Calcium chromate $\mathrm{TCaChr}_{3}=$ Treated with $2.0 \%$ Calcium chromate. TLC Total Leucocyte CountN= Neutrophil $\mathrm{M}=$ Monocyte $\mathrm{E}=$ Eosinophil $\mathrm{L}=$ Lymphocyte B=Basophil

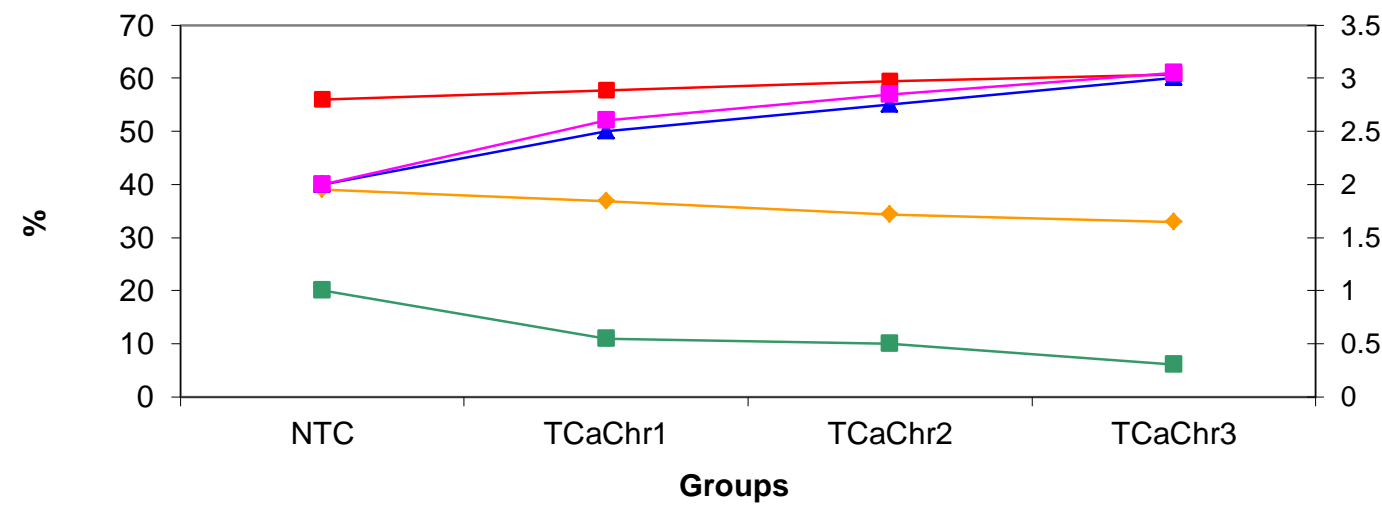

2

Fig.1: Differential Leucocyte Count (After 24 Hours) in Mice Treated with Calcium Chromate 
Experimental studies on leucocyte response in

Table 2: Statistical comparison of haematological values after 24 hours of exposure in mice treated with calcium chromate (' $t$ ' values obtained from the data given in Table 1)

\begin{tabular}{|l|l|l|l|l|l|l|l|}
\hline \multirow{2}{*}{ Gr. } & Group & \multicolumn{6}{l}{ Differential Leucocyte Count } \\
\cline { 3 - 8 } No. & Comparison & TLC & N & L & M & B & E \\
\hline 1. & 1 Vs 2 & 700 & 4.54 & 3.17 & 7.69 & 7.14 & 21.47 \\
\hline 2. & 1 Vs 3 & 1679 & 12.53 & 10.22 & 5.89 & 4.76 & 35.71 \\
\hline 3. & 1 Vs 4 & 2131 & 18.80 & 18.80 & 21.89 & 10.71 & 32.14 \\
\hline 4. & 2 Vs 3 & 365 & 7.75 & 3.24 & 3.22 & 7.14 & 12.5 \\
\hline 5. & 2 Vs 4 & 684 & 12.91 & 5.65 & 25.97 & 3.12 & 9.37 \\
\hline 6. & 3 Vs 4 & 391 & 4.54 & 2.77 & 3.12 & 10.71 & 3.12 \\
\hline
\end{tabular}

Standard value of ' $\mathrm{t}$ ' at $5 \%$ level and $8^{\circ} \mathrm{F}$ is 2.306 . All' $\mathrm{t}$ ' values are significant. In the present study there was a significant increase in the count of total leucocytes, lymphocytes, monocytes and eosinophils, (Table 2) which was positively correlated with the concentration of the test compound. This indicated the enhancement of immune response.

Neutrophils migrateto the site of inflammation caused by $\mathrm{Cr}$. and therefore reduce in number in peripheral blood. Miyazato et al. (1979) and Kaskhedikar et al. (1993) also observed a remarkable infiltration of neutrophils and eosinophilsat the site of inflammation / tissue destruction. Acute tissue destruction leads to histamine release, vasodilation and cellular infiltration (Katiyar and Sen, 1970). These infiltrated cells play an important role in allergy.

Decrease in nutrophil count may also possibly be due to their transformation into other type of cells, such as the macrophages and lymphocytes. Neutrophils and lymphocytes are always reciprocally related to each other. Lymphocyte count was found to be increased in the present study, indicating their role in delayed hypersensitivity reactions.Eosinophils, a class of granular leucocyte are prominent in allergic reactions, during exposure to $\mathrm{Cr}$ (Glaser et ai., 1985) and in helminthIc infections (Kaskhedikar, 1990; Kaskhedikar et al., 1993). Eosinophils play an important role in immune mechanism and their increased count is T-cell dependent, as the T-cells recruit eosinophils into the areaof the skin which is exposed to allergen. Monocytes are in circulation in the blood and fixed on connective tissue under the skin. In sensitized animal the circulating monocytes are assigned to get fixed as the macrophages. Therefore, their number increases in the blood so that large number of monocytes can reach the site of the allergen to get fixed as macrophages. Macrophages act as active phagocytes, which contain enzymes capable of digesting the phagocytosed material, if indigestible then store it away so that it does not behave as a local irritant.

Fluctation in the count of basophil may be for compensating the altered number of other blood cells. In the present investigation increase in the differential leucocytecounts, particularly eosinophils, lymphocytes and monocytes is a clear indication of their role in destruction of allergen. Pharmacological ediators released following degranulation of these cells play an important role in allergic reactions. It also emphasizes that delayed hypersensitivity reactions induced by chromium are mediated through these sensitized cells.

\section{Conclusion}

Chromium is hazardous to man and animals. A number of effects on skin can result from occupational exposure to Cr. Skin rashes; ulcer, sores and eczema have been reported among occupational exposed workers. Hexavalent chromium compounds can give rise to sensitization of skin. Thus the main objective and central idea of the proposed study is to find out the adverse effects of $\mathrm{Cr}$ on mammals. The major interest of the present study is the evaluation of the results of toxicity testing in rodents for the purpose of risk assessment for human. The present investigation would throw light on the delayed hypersensitivity response induced by exposure to hexavalent chromium used in various industries. 


\section{References}

ATSDR 1989. Agency for Toxic Substance and Disease Registry.Toxicological profile of chromium prepared by syracuse research corporation. U.S. public health service.ATSDR 88/10

Daugherty, M.L. 1992. Toxicity summary for chromium Chemical Hazard Evaluation and Communication Group, Biomedical and Environmental Information Analysis Section. Health and Safety Research Division, Oak Ridge, Tannessee

Edmundson, W.P. 1951. Chrome ulcer of skin and nasal septum and their relation to patch testing. 1. Invest Dermato 17: 17-19

EHC-61- Environmental Health Criteria 61 1988. International Programme on Chemical Safety. WHO Publication, 17-18.

Fregert, S. 1975.Occupational dermatitis in a 10-years material. Contact Dermatit., 1 : 96-107.

Glaser, U., D. Hochrainer, H. Kloppel and H. Kuhnen 1985.Low level Chromium VI inhalation effects on alveolar macro phages and immune functions in Wistar rats. Arch. Toxicol., 57:250-256.

Harold, Varley 1988. In: Practical Clinical Biochemistry. 4th Edition, CBS Publishers, New Delhi.

Kaskhedikar, P. 1990. Effect of malathion exposure to" the intestinal eosinophilic response of albino mice experimentally infected with Hymenolepisnana, 1 . Hydrobio/., VI(J) : 7-9.
Kaskhedikar, P, L. FernancRz, D. Chaskar and R. Chaskar 1993. Intestinal histopathological changes in Cysticercosis during experimental Hymenolepis nana infection in albino mice.Indian J Parasitol.17(2) 165-167.

Katiyar, J.C. and Sen, A.B. 1970.Occurrence of histamine in the intestine of rats harbouring cysticercoids of Hymenolepis nana. Indian J. Expt. Biol., 8, 191-193.

Kvitko, E. 2001. Occupational contact dermatitis in the tanning industry. Contact Dermatitis, 45, 256-259.

Luster, M.I., Simeonov, P., Gallucci, R., Matheson, J., Yucesoy, D. and Sugawara, T. 2000. Overview of immunotoxicology and current application to respiratory diseases.Immunopharmacology , 43(3), 311-312.

Miyazato, T., Furukawa, T. and Inove, T. 1979. Intestinal pathology associated with primary and secondary infection of Hymenolepis nana in mice. Jpn. J. Parasitol, 28(4), 185196.

Raj Gopal, G. and Ramakrishnan, S. 1983. Practical biochemistry for medical students. Ed.1, Published by Orient Longman Ltd., Hyderabad.

Shrivastava, R., Upreti, R.K., Seth, P.K. and Chaturvedi, U.C. 2002.Effect of chromium on the immune system. Federation of European Microbiological Societies.Immunology and Medical Microbiology, published by Elsevier Science V.V., 34, 1-7. 